\title{
The Link Between Money and Prices in an Open Economy: The Canadian Evidence from 1971 to 1980
}

\author{
MICHAEL D. BORDO and EHSAN U. CHOUDHRI
}

\begin{abstract}
6.
W INCE 1970, Canada ostensibly has followed a flexible exchange rate policy that should have allowed their monetary authorities to focus directly on controlling the Canadian inflation rate. Since 1975, the Canadian monetary authorities have been publicly committed to reducing inflation by a policy of gradually reducing the rate of monetary growth. Yet Canada has fared no better than the United States and other industrialized economies in controlling inflation during the $1970 \mathrm{~s}$. As table 1 shows, the average rate of Canadian money growth decreased from about 13 percent in 1971-75 to 8 percent in $1976-80$, while the average rate of inflation remained unchanged at about $81 / 2$ percent in these two periods.
\end{abstract}

In this paper, we use a quantity theory framework to examine Canadian inflation over the past decade. In addition to assessing the impact of money growth on price changes, we test for the influence of other factors commonly believed to have contributed to Canadian inflation, for instance, the relative price of energy. Canadian wage-push and the rate of unemployment. Finally, we examine the infuence of U.S. monetary growth and inflation on Canadian money growth and inflation. We find that Canadian inflation is largely explained by lagged Canadian money growth. Furthermore, we determine that Canadian monetary policy has not been independent from that of the United States: we find evidence of a link between Canadian and U.S. monetary growth in addition to a direct link between the U.S. and Canadian inflation rates.

\footnotetext{
* Michael D. Bordo is a profesor of econtmics at the University of South Carolina. Ehsan $U$. Choudhri is an associate professor of economics at Carleton University. This article was written while Professor Bordo was a wisting scholar at the Federal Resere Bank of St. Louts.
}

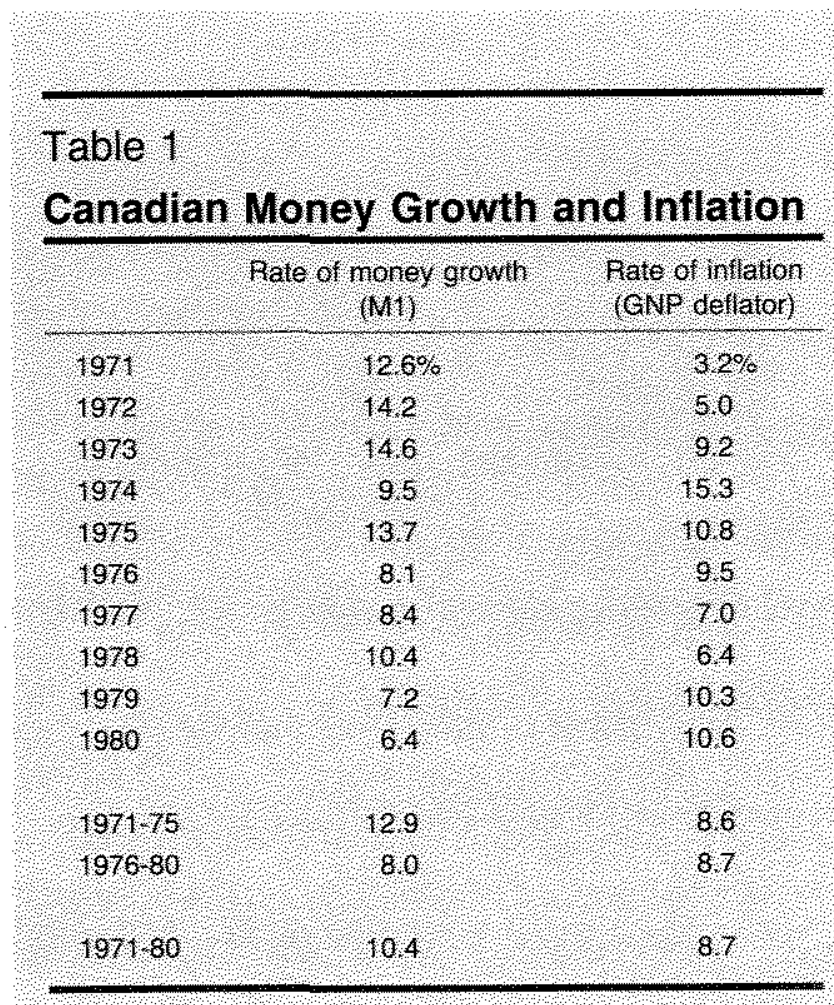

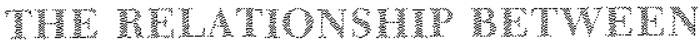

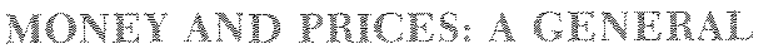

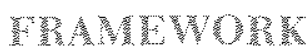

One way to enhance our understanding of a complex system is to begin with a simple model of that system. Thus, it is instructive to consider first an economy in which market information is transmitted rapidly, and prices and wages adjust smoothly to maintain equitibrium continuously in all markets. 


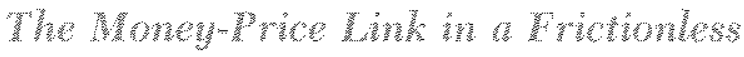

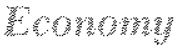

In a smoothly operating, frictionless economy, the rate of change in prices would be determined largely by the rate of growth in the money stock. This can be derived from the well-known quantity theory of money. The quantity theory is usually written as:

(1) $\mathrm{MV}=\mathrm{PY}$

where $M$ is the stock of money, $V$ is the velocity with which money circulates the number of times money is used on average to finance final transactions), $P$ is the price level and $\mathrm{Y}$ is the level of real income or output. According to the modern version of the quantity theory, $V$ is a stable function of a few variables such as long-term income, interest rates and inflationary expectations. If $\mathrm{V}$ is constant or changing at a steady rate and $Y$ is growing at a steady rate, changes in $P$ would be directly related to changes in $M .^{2}$ Expressed as rates of change, the quantity theory can be expressed as:

(2) $\dot{\mathrm{p}}=\dot{\mathrm{n}}+\dot{\mathrm{u}}$,

where lowercase letters represent the values in natural logarithms and a dot indicates a first difference. Thus, $p$ is the rate of change in the price level, in is the rate of change in the money stock and $\dot{u}$ is a residual term that represents the diference between the rate of change in velocty and that in output $(\dot{u}=\dot{x}-\dot{y})$.

If output and velocity grow at the same long-term rate, the avenge value of $u$ would equal zero and the average rate of infation per year would equal the rate of monetary growth. Deviations in velocity or output growth from their long-tern trend values could cause the value of $x$ to devate temporarily hom zero. To the extent that such changes are transitory. hey on term porariy inhence the rate of intation. 3 in this sense, intation is essentally anonetary phemomenon; that is, conthous growth in the money supply is necessary to sustanin th.

In the above enviromment, fnctors sich as increases in eiher rea wages (brough about, say, by aggressive

\footnotetext{
See Nhlon Fredman, A Theoretical Framework for Wonetary

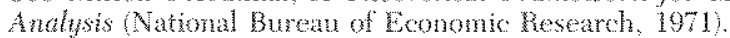

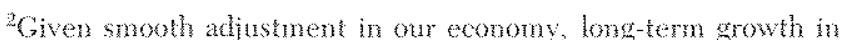
real oupu would depend ssentaly on hetors such as techolotical atvare and posalabon growe.

3 Fon a discussion of the infuence of nommonetar hotors such as a suphy show on the price level and the rate of price changes set

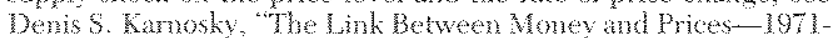
$1976, "$ this Rever Uune 1976 , pp, $17-23$.
}

labor unions) or the relative price of energy could play only a limited role in explaining the rate of inflation. These factors could temporarily affect $\dot{u}$ (via their potential effect on full-employment output and velocity), but as long as there is no monetary accommodation-that is, as long as $m$ is not influenced by these factors-their effect is likely to be short-lived.

Furthermore, in a frictionless economy, no special problem is created if the domestic rate of inflation differs from those in other countries. In such a case, the exchange rate could adjust continuously to reconcile differences between domestic and foreign rates of inflation. ${ }^{4}$ For instance, if the domestic rate of inflation is 10 percent and the rate of inflation in the foreign economy is only 5 percent, the exchange rate-denoted as the number of units of the foreign currency that could be purchased by one unit of the domestic currency-would depreciate by 5 percent in each period and only this specific depreciation would keep the relative price of domestic and foreign goods the same.

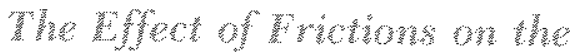

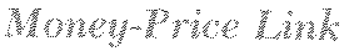

We do not he in a frictionless world. There are frictions in the adjustment process, for example, that arise from lags in the transmission of price information from one market to another and from inertia in the movement of wages and prices. Given these information lags and temporary wage-price inflexibilites, the effect of monetary growth on inflation will not be refected fully in one period; rather, it will be distributed over a number of periods. ${ }^{6}$ Taking these lags into account, the relationship between money and prices can be modeled as

$$
\text { (3) } \mathrm{p}=\dot{\overline{\mathrm{m}}}+\varepsilon
$$

\footnotetext{
Heal fotors, such as changes in tastes, techology on the supples of factors of production, also can affect the exchange rate.

Intomation lage have been emplasized by Robert $\mathrm{E}$. LAcas, "Ex-

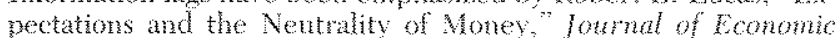
Theory April 1972, pp. 103-24, "An Equibrim Nodel of the

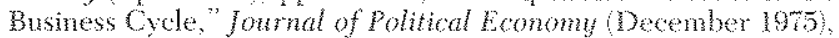

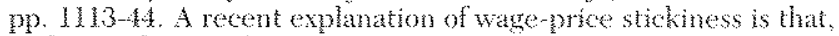

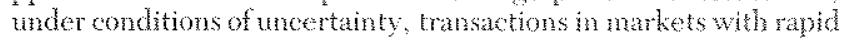
price a diustments are cost $\psi$ and therefore waves and prices may be changed intrequenty to save these transuction costs see

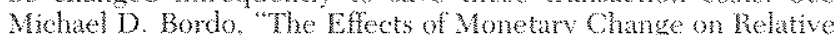

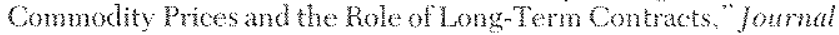

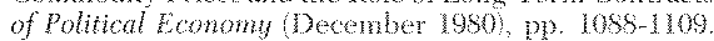

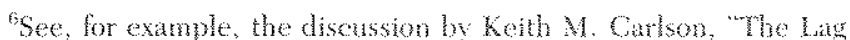

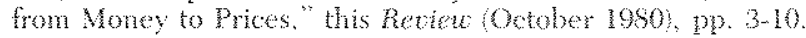


where $\dot{\vec{m}}$ is some weighted average of past monetary growth rates - call it the long-term or trend rate of monetary growth-and $\varepsilon$ is a residual term.

Several caveats, however, should be added to this simple representation of the lag between money and prices. First, theoretical analysis does not specify the pattern of weights that should be used in calculating the long-term monetary growth rate-it must be discovered empirically. Also, because these weights represent the lags between money and prices embedded in a particular policy regime and institutional setting, they will shift with significant changes in policy and institutions. ${ }^{7}$ Second, $\varepsilon$ represents the influence of all factors other than monetary growth. The effect of these factors also operates with lags and cannot be simply dismissed, at least theoretically, as a temporary deviation. Finally, in a nonfrictionless economy, the exchange rate need not change smoothly to offset exactly the difference between foreign and domestic inflation rates. ${ }^{8}$ Thus, the economy generally will not be immune from the influence of inflation in the rest of the world.

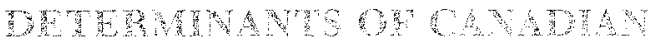

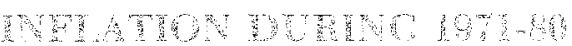

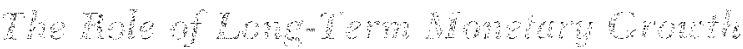

We begin by examining the influence of long-term monetary growth. As discussed above, the specific long-term monetary growth rate that best explains inflation must be estimated empirically. We found that, for the I/1971-IV/1980 period, a simple 12 quarter average of past growth rates of Canadian Ml provides an adequate measure of the long-term monetary growth rate for Canada. ${ }^{9}$ The effect of long-term

'For instance, Robert E. Lucas, "Econometric Policy Evaluations," in Karl Brumer and Allan H. Meltzer (eds.), The Phillips Curve and the Labour Market (North Holland, 1976), has argued that the structure of the economy depends upon the conduct of policy.

"See Jacob Frankel, "The Collapse of Purchasing Power Parities During the 1970s," European Economic Review (February 1981), pp. 145-65.

${ }^{9}$ We regressed the rate of inflation on the simple average of past monetary growth rates, using three alternative definitions of money (M1, MlB and M2) and alternative averaging periods, differing by two-quarter intervals $(2,4,6 \ldots)$. A 12-quarter average of $\mathrm{Ml}$ worked best in the sense of giving the lowest stindiard error of the regression. This procedure constrains the weights on past growth rates to be equal. To test this constraint, we estimated the following regression:

$$
\dot{p}_{1}=a+\sum_{i=1}^{12} b_{i} \dot{m}_{1-i}+e .
$$

In the above regression, the hypothesis that $b_{1}=b_{2} . . b_{12}$, could not be rejected at the conventional 5 percent level. Finally, note monetary growth, thus measured, on the quarterly rate of inflation in Canada is shown in regression equation 1 in table 2 and is illustrated in chart 1. The chart shows: (a) the actual rate of inflation measured by the quarter-to-quarter change in the GNP deflator over the period and (b) the rate of inflation predicted by the long-term monetary growth rate from equation 1 in table 2 .

As chart 1 shows, the predicted rate traces quite well the sharp rise in the inflation rate up to 1974 and the gradual decline in the subsequent three years. The chart also shows that the inflation rate was much higher than the predicted rate in 1974 and, more recently, in 1979 and 1980 .

To facilitate a comparison between the U.S. and Canadian inflation experience, chart 2 presents the actual and predicted rates of inflation in the United States using the same procedure as for the Canadian data (regression estimates for the United States are slown in equation 4 , table 2 ). ${ }^{10}$ As in the Canadian case, the simple 12-quarter average of M1 growth predicts inflation quite well. Note, however, that the predicted rate shown in the chart also includes the effect of price controls in the United States.

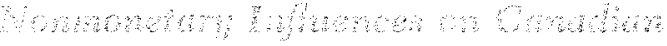 Whesh}

Having accounted for the direct impact of monetary growth on the Canadian inflation rate, we now consider certain nonmonetary factors that are potential causes of the residual inflation rate (the difference between the actual inflation rate and the rate predicted by long-term monetary growth). First, it is possible that the Canadian wage and price controls adopted at the end of 1975 and terminated in the third quarter of 1978 had some impact on Canadian inflation. If these controls were effective, the residual inflation rate

\footnotetext{
that we have not constraned the coefficient of in (i) 12 $\left.\sum \dot{n}_{\mathrm{t}-\mathrm{i}} / 12\right)$ to be equal to unity. $\mathrm{i}=\mathbf{l}$

${ }^{10} \mathrm{~A} 12$-quarter average of $\mathrm{M} 1$ worked best for the U.S. data. The U.S. evidence also was consistent with the hypothesis that the weights on lagged monetary growth rates are all equal. In the U.S. regression, we also have included price-control and decontrol dummies as defined in Carlson's paper.

Note that the coefficient on $\dot{\bar{M}}>1$ may reffect the impact of higher energy prices in the United States which are not captured explicitly in the U.S. equation. See Carlson, "The Lag from Money to Prices." This paper also provides estimates of the U.S. moneyprice relationship using Almon lags and including additional variables. Also see John A. Tatom, "Energy Prices and Short-Run Economic Performance," this Review (January, 1981), pp. 3-17.
} 
Table 2

Estimates of the Money-Price Relationship in Canada and the United States: V/1971-IV/1980

\begin{tabular}{|c|c|c|c|c|c|c|c|c|c|}
\hline & Equation & Constant & 6 & buMe & buna & 3 & DW & $\mathrm{h}$ & $\mathrm{se} \times 1,0$ \\
\hline Canade & $(1)$ & ४ 000 & ৫) 72 & & & & 2,14 & 375 & 725 \\
\hline & (2) & ४४ 007 & 1205 & 4,005 & 009 & & 1.94 & 525 & 687 \\
\hline & (3) & 4008 & 1,19 & 4005 & 009 & 190 & 233 & 597 & 641 \\
\hline Whied states & (4) & 14006 & 1555 & 14004 & 008 & & 188 & 706 & 316 \\
\hline & & $(1+75)$ & $(6,66)$ & $(4338)$ & $(409)$ & & & & \\
\hline
\end{tabular}

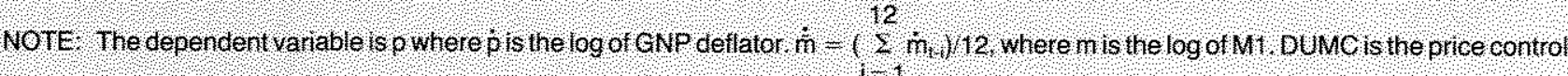

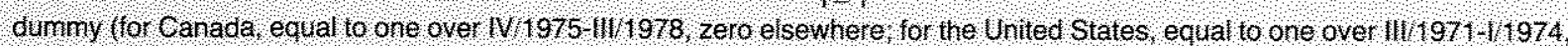
zero elsewhere). DUMA is the dunny tor the after-control period (for Canada, equal to one over W1978.1111979, zero elsewhere: tor the United States, equal to one over 11974 V/ 1974 , zero elsewhere), r represents the log of an ndex of energy prices divided by the GNP detlato, $\mathrm{R}$ is the coefictent of detemination cortected for degrees of freedom, SE is the regresslon standard error and DW is the Durbin Watson statistic (t values are shown in parentheses)

Equation 1 is estimated using cochrane orcutt adjustment with $\rho=357$

should be negative during the period of controls and positive immediately thereafter. ${ }^{11}$ This pattern is suggested by chart 1 and is confirmed by equation 2 in table 2 , where the price control dummy (DUMC) is significantly negatice and the dummy variable for the one-year period following the end of controls (DUMA) is significantly positive.

Second, the relative rise of energy prices, which has been regarded as a significant factor in explaining U.S. inflation, could similarly have affected Canadian prices in the $1970 \mathrm{~s} .{ }^{12}$ This hypothesis is supported by equation 3 in table 2, which shows that a four-quarter average of changes in relative energy prices has a significant positive effect on the Canadian inflation rate. ${ }^{13}$

\footnotetext{
${ }^{13}$ For al further discussion of the Canadian experience with controls, see the articles by Michael Parkin and Jack Carr in lack Cart et al. eds. The Illusion of Wage and Price Control Vancouver: The Fraser Institute, 1976).

${ }^{12}$ Tatom, "Energy Prices and Shorthun Economic Performance."

${ }^{13}$ Averages of relative energy prices for two, six and eight quarters also were considered, but the four-guarter average produced the strongest effect. The evidence also was consistent with the constrant (implict in the simple four-quarter average) that the coef
}

A third explanation that invariably arises in inflation discussions is that the rising prices were caused, at least in part, by wage-push. ${ }^{1 / 2}$ In Canada we found that the rate of monetary growth is not systematically related to (current or past) wage changes and, thus, there is no direct evidence that the Bank of Canada followed a policy of validating wage increases by accelerating the growth in money. ${ }^{15}$ Even without monetary accommodation, wage-push elements may still have influenced the residual inflation rate, at least in the short run. This possibility also was rejected by the Canadian evidence, which shows that the rate of wage change (in the current and past three quarters) does

ficients of current and three lagged energy-price terms were all equal.

"See Dallas S. Batten, "Inflation: The Cost-Push Myth," this Review (lune/Tuly 1981) क эp. 20-26.

${ }^{15}$ Current and ap to four lagged values of the rate of change in the watge index (hourly wage rate of manufacturing sector were introduced in an atutoregression of the rate of monetary growtl (MI) containing four of its own lagged values. All wage terms were insigniffant in this regression estimated for the period $\mathrm{V} / \mathrm{197} \mathrm{I}-\mathrm{IV}$ / 1980). Also, see the evidence in Robert J, Gordon, "World InflaWon and Monetary Acommodations in Eight Countries, "Brook. ings Papers on Economic Actitity (2:1977), pp. 409-68. 
Chart 1

\section{The Actual Vs. Predicted Rate of Inflation in Canada}

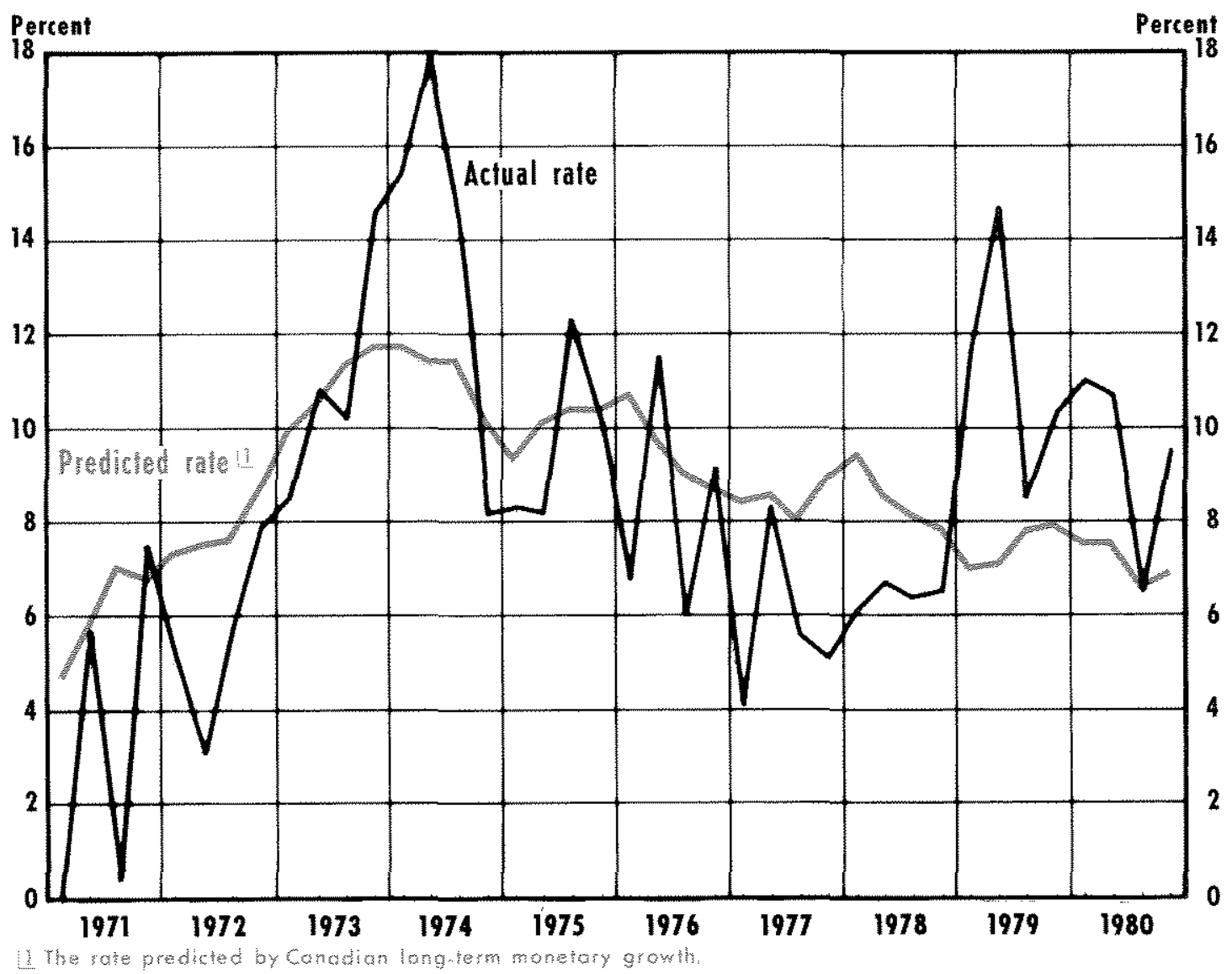

not exert a significant effect in the money-price regression. ${ }^{16}$

A fourth explanation, suggested by the Phillips curve theory, is that the residual rate of inflation may reflect the effect of excess supply or demand in goods and/or labor markets) as measured by the unemployment rate ${ }^{17}$ This explanation also was tested and rem

${ }^{16} \mathrm{~W}_{\mathrm{e}}$ estimated the following regression equation:

$$
\dot{p}=a_{0}+a_{1} \dot{\bar{n}}+a_{2} \text { DUMC }+a_{5} \text { DUMA }+a_{4} \dot{\bar{r}}+\underset{i=0}{\stackrel{3}{2} b_{i} \dot{w}_{i} \ldots i}
$$

where w represents the log of the hourly wage rate in Canadian manufacturing, and other variables are as defined in table 1 . In this regression, $b_{i}$ 's were insignificant endividually as well as joint ly. A fourquarter average of $w$ 's was tried, but its effect also was insignificant.

${ }^{17}$ In the standard version of the Phillips curve theory, a priceexpectation fem is added to the unemployment rate. See, for example, Rudiger Dornbusch and Stanley Fischer, Macroeconomies, 2nd ed. McGraw-Hill, 1980, The above variant, in fact, jected: the effect of the unemployment rate (in the current and past three quarters) is insignificant when introduced in the regression containing the long-term monetary growth rate. ${ }^{18}$

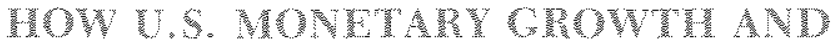

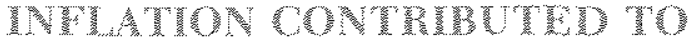

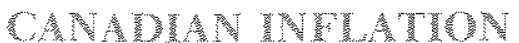

Monetary growth and inflation in the United States could have influenced the Canadian rate indirectly through their impact on Canadian monetary growth,

tepresents a monetary-growth-augmented Phillips curve

${ }^{15}$ As in the case of wage index, the coefficients of the current and three lagged values of the unemployment rate were insignificant both individually and jointly when added to the money-price regression (incliting control dummies and $\dot{\hat{r}}$ ). A four quarter average of the anemployment rate also did not prodtuce an significant effect. 


\section{Chont 2 \\ The Actual Vs. Predicted Rate of Inflation in the United States}

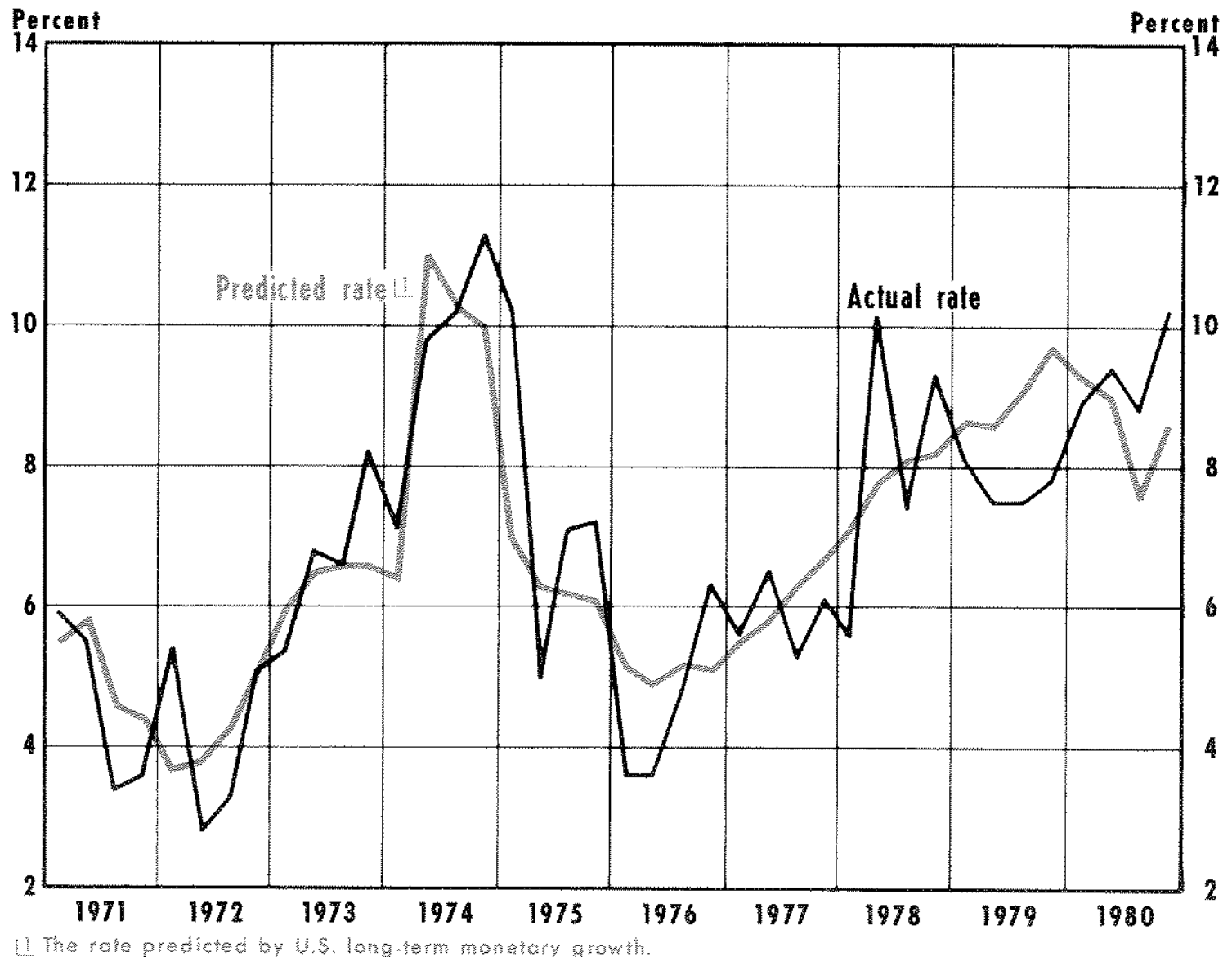

directly through their impact on the residuat inflation rate in Canada, or both. The possible chanmels are presented in the flow-chart in figure 1. Both of these channels are examined here

\section{The Pmonet of U.S. Mongy Growth on Canadions Monen Cromh}

During the $1970 \mathrm{~s}$, despite the nommal existence of a flexible exchange rate system, the Bank of Canada often has attempted to control the movement of the Canadian- $\mathrm{L} . \mathrm{S}$. dollar exchange rate. This exchange rate intervention may have established a link between the Canadian and U.S. monetary growth. Because the Bank engages in interest-rate control to implement monetary policy, Canadian money growth is likely to be linked to U.S. money growth via interest rates in the two conntries. ${ }^{19}$ For instance, the Bank of Canada generally acted to move Canadian short-term interest rates in the same direction that the U.S. rates moved, in order to avoid large fluctuations in the exchange rate. ${ }^{20}$ The positive relationship between Canadian

\footnotetext{
"Since 1975 the Bank of Canada began amouncing target tainges for the growth of M 1 . However, it has continued to use the control of short-term interest tates as the policy instrument in the short rim. For a further diseussion of the Bank of Canadas approah to monetary policy, see Thomas I. Courchene, "On Defining and Controlling Money," Canadian Joumal of Economics November 1979), pp. 604-15.

20The relationship between the Canadian-U.S. interest rate dif ferential and the exchange rate could be either positive or negative depending on whether the interest acte differential represents differences between expected inflation ates or real interest rates in the two comtries. For a further inscussion of the relationship between the exchange rate and interest rates, see Dallas S. Batten, "Foreign Exchange Market: The Dolla in 1980" this Revien (April 1981), pp. 22-30.
} 


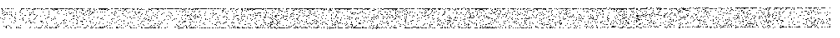

Figure 1

The Transmission of U.S. Money Growth to Canadian Inflation

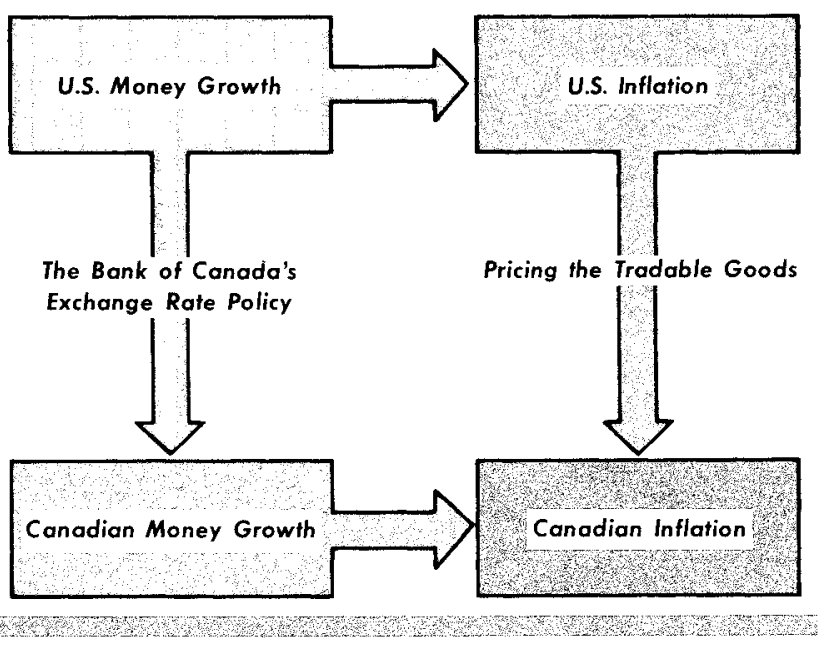

and U.S. interest rates arising from this policy also is likely to imply a positive correlation between rates of monetary growth in the two countries. ${ }^{21}$

To explore whether Canadian money growth is systematically related to U.S. money growth, we regressed the monetary growth rate in Canada on current and lagged values of the U.S. monetary growth rate. The results show a statistically significant, synchronous relationship between the rates of growth in Canadian M1 and U.S. M1A. ${ }^{22}$ Thus, the Bank of Canada's exchange rate policy appears to have established a link between U.S. and Canadian money growth. This link opens up a channel through which U.S. money growth can influence Canadian inflation. ${ }^{23}$

${ }^{21}$ The direction of the relationship between monetary growth and the rate of interest in each country also would depend on whether interest rate changes reflect changes in expected inflation or real interest rates. We assume that the direction of this relationship is the same in both Canada and the United States

${ }^{22}$ The estimated regression equation is:

$$
\begin{aligned}
& \dot{\mathrm{m}}_{\mathrm{f}}^{\mathrm{ca}}=.012+.894 \dot{\mathrm{m}}_{\mathrm{t}}^{\mathrm{L} s} \\
& \text { (1.96) }(2.40) \\
& \mathrm{DW}=1.98, \mathrm{R}^{2}=.13, \mathrm{SE}=.0164
\end{aligned}
$$

where $\mathrm{m}^{\mathrm{ca}}$ and $\mathrm{m}^{\mathrm{US}}$ represent the logs of Canadian M1 and U.S. M1A. Up to four lagged values of $\dot{\mathrm{m}}^{\text {is }}$ also were introduced in the regression but their effect was found to be insignificant at the 5 percent level. Using MI as an alternative measure of the U.S. money supply, the results of the above tests were similar, but the effect of U.S. MI on Canadian MI was weaker than U.S. MIA. (Using U.S. MI instead of U.S. MIA, the coefficient of $\dot{\mathrm{m}}_{\mathrm{t}}^{\text {US }}$ was equal to .666 in the above regression, with a t-value of 1.74 .)

${ }^{23}$ Of course, the synchronous relationship between Canadian and U.S. money growth does not, by itself, imply anything about the direction of causation. We assume, however, that U.S. monetary policy actions are independent of Canadian monetary policy.
The effect of operating through this channel is illustrated in chart 3 . In this chart, we show both the actual rate of long-term Canadian monetary growth and the rate induced by U.S. monetary growth because of Canadian exchange-rate intervention. ${ }^{24}$ The difference between the two rates can be viewed as the result of Canadian monetary policy actions not related to exchange market intervention.

Two interesting points emerge from this chart. First, the portion of Canadian money growth induced by U.S. money growth has been sizable and relatively stable throughout the period (it has varied between 4.2 and 6.I percent per year). Second, the residual growth rate, as represented by the gap between the actual and the U.S.-induced rates, rose sharply in the early 1970 s but has been declining gradually since the mid-1970s. Thus, the Bank of Canada's anti-inflation policy adopted in 1975 appears to be effectively reducing the nonintervention portion of Canadian money growth, while having little impact on the contribution of foreign exchange market intervention to money growth.

\section{Whe Whant की Hentrin}

The Canadian rate of inflation also may be directly related to the U.S. inflation rate because of price linkages between Canadian and U.S. tradable goods. According to one hypothesis about these price linkages-called the "law of one price"-the Canadian price for goods produced both in the United States and Canada is the same as the U.S. price adjusted for the exchange rate. According to this hypothesis, the Canadian rate of inflation would depend on the U.S. rate of inflation adjusted for changes in the exchange rate ${ }^{25} \mathrm{It}$ should be pointed out that even if Canadian money growth were held constant and there were no intervention in the exchange market, an increase in the U.S.

\footnotetext{
${ }^{24} \mathrm{U}$ sing the regression equation relating $\dot{\mathrm{m}}^{\mathrm{ca}}$ to $\dot{\mathrm{m}}^{\text {is }}$ in footnote 22 and averaging over 12 quarters, the long-term monetary growth in Canada equals:

$$
\dot{\overline{\mathrm{n}}}^{\mathrm{ca}}=.012+.894 \dot{\overline{\mathrm{m}}}^{\mathrm{L} \mathrm{S}}+\mathrm{u},
$$
}

where $u$ is the 12 quarter average of the residual error in the regression equation in footnote 22 . From the above equation, we estimate the amount of Canadian long-term monetary growth induced by U.S. long-term growth to be equal to $.894 \mathrm{~m}^{\mathrm{uS}}$.

${ }^{25}$ For individual tradable goods, the law implies that the rate of change in the Canadian price would equal the rate of change in the U.S. price, plus the rate of appreciation of the U.S. dollar. The relationship between inflation rates in the two countries, however, would be generally weaker because: (a) some nontraded goods would be included in each country's aggregate price index and (b) the weights used in the aggregate index may be different for the two countries. 
Chart 3

\section{The Contribution of U.S. Long-Term Monetary Growth to Canadian Long-Term Monetary Growth}

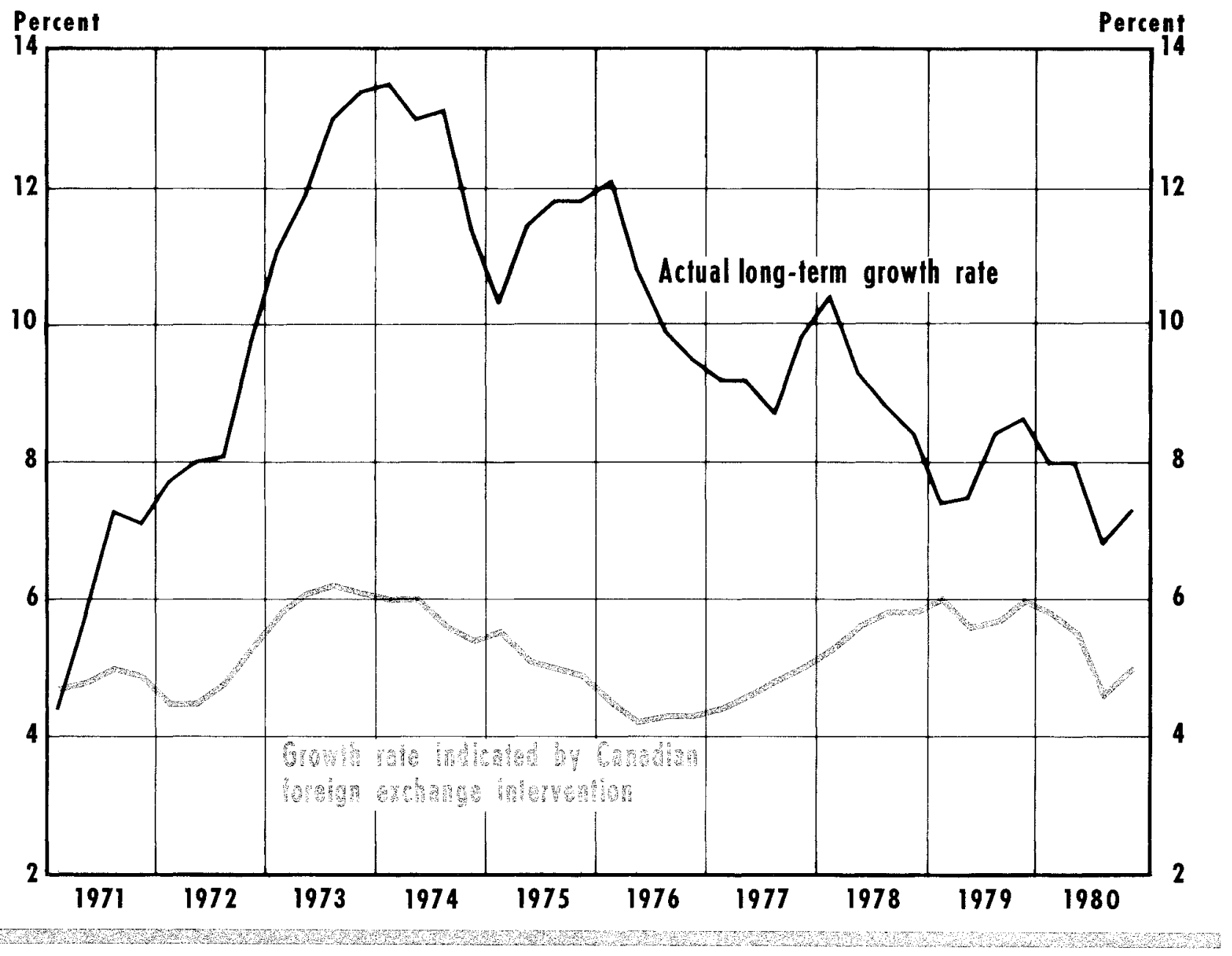

inflation rate need not be accompanied by an equal depreciation of the U.S. dollar in the short run. U.S. inflation, therefore, could temporarily affect the residual rate of inflation in Canada. ${ }^{26}$

The simple version of the law of one price is based on the assumptions that the costs of making price changes and undertaking arbitrage are negligible, the goods produced in the two countries are identical in all re-

\footnotetext{
${ }^{26}$ In terms of the quantity theory framework, the above effect implies that U.S. inflation can temporarily influence the rate of growth in velocity and/or output in Canada. Such an impact is possible in open-economy models which allow for capital mobility and/or distinguish between traded and nontraded goods. For a discussion of monetary adjustment in open-economy models, see Rudiger Dornbusch, Open Economy Macroeconomics (Basic Books, 1980).
}

ary Growth

ary Growth tionship implied by the law of one price could be significantly altered. ${ }^{27}$ For instance, if prices are costly to change, domestic prices may not respond to those changes in foreign prices and the exchange rate that are perceived to be transitory. ${ }^{28}$ This modification of the law of one price suggests that Canadian price changes

${ }^{27}$ For empirical evidence on the depatures from the law of one price, see Irving B. Kravis and Robert E. Lipsey, "Price Behaviour in the Light of Balance of Payments Theories, Journal of International Economics (2:1978), pp. 193-246.

${ }^{28}$ The costs of making price changes would include not only administrative and labeling costs, but also the costs associated with advertising price changes, adverse reaction from customers and uncertainty about the response of competitors. 


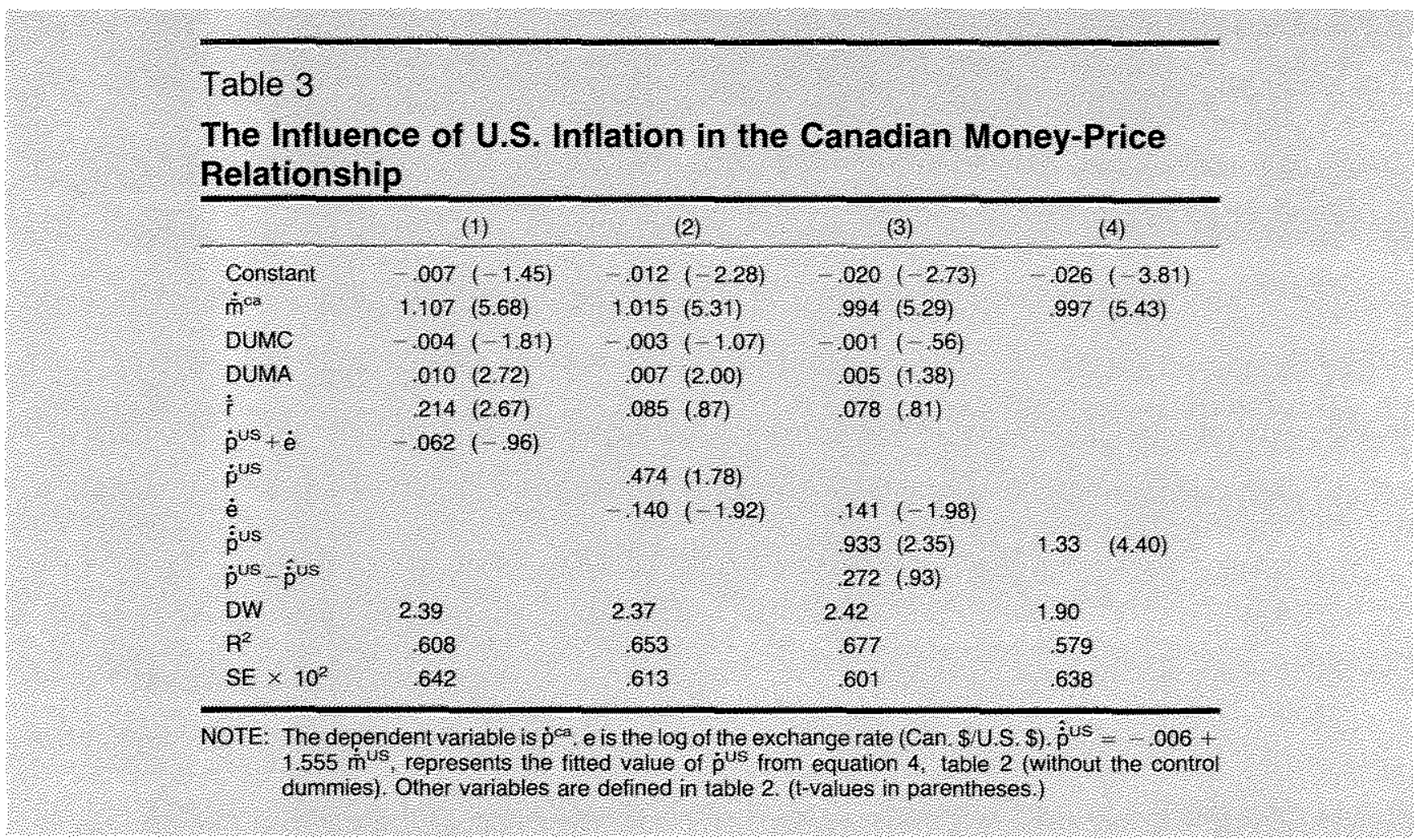

are related to long-term movements in U.S. prices and the exchange rate.

To explore the direct link between the U.S. and Canadian inflation, we experimented with a number of tests. First, we added the exchange-rate-adjusted U.S. inflation $\left(\dot{\mathrm{p}}^{\mathrm{Us}}+\dot{\mathrm{e}}\right.$, where $e$ is the logarithm of the price of the U.S. dollar in Canadian dollars) to the moneyprice regression including price-control dummies and the relative energy price. As shown in equation 1, table 3 , the effect of this variable is insignificant. ${ }^{29}$ Next, we included the U.S. inflation rate $\left(\dot{\mathrm{p}}^{\mathrm{is}}\right)$ and the exchange rate change ( $\dot{e})$ as separate variables in the regression equation. In this test (see equation 2, table 3), while the U.S. inflation rate has a positive effeet, the effect of the exchange-rate change is negative (both variables are significant at the 10 percent level, though not at the 5 percent level) ${ }^{30}$ We are, thus, unable to find a consistent effect of the exchange rate on Canadian inflation. One explanation of this is that the exchange rate exhibited little or no time trend during the flexible

\footnotetext{
${ }^{29} \mathrm{Up}_{\mathrm{p}}$ to three lagged values of the exchange-rate-adjusted $\mathrm{U}, \mathrm{S}$. inflation also were added to the regression, but their effects renained instgnificant.

${ }^{30}$ Again, up to thee lagged values of both $p^{\text {is }}$ and 2 were introduce in the regression, but none of these terms produced a significant effect $A$ four-quarter average of e was tried, but this variable also had an insignificant influence.
}

exchange rate period. ${ }^{3}$ Its movements, therefore, could have been considered transitory and largely disregarded in the adjustment of Canadian prices.

Finally, to examine the possibility that transitory and trend changes in U.S. prices may exert different effects on Canadian inflation, we divided the U.S. inflation rate in two parts: (a) the rate predicted by

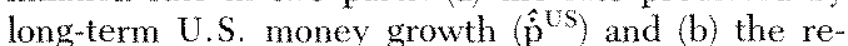
sidual rate $\left(\dot{\mathrm{p}}^{\mathrm{US}}-\hat{\mathrm{p}}^{\mathrm{US}}\right)$. Each part was entered in the regression equation separately. As shown in equation 3 , table 3 , this test produced the interesting result that, although the effect of the U.S. monetary-induced trend rate of inflation is positive and significant, the effect of the residual rate is insignificant. It is also interesting to note that the effect of both price-control dummies as well as that of the relative energy price is insignificant in this regression. ${ }^{32}$ In equation 4 , table 3 , we present the regression equation that emerges when

\footnotetext{
HFrom IL/1970 to IV/1980, the exchange rate changed by only 12 percent. The U.S. aggregate price level changed by 102 percent over the same period.

${ }^{32}$ As these variables are correlated with the U.S. inflation rate, it is difficalt to disentangle their separate intuences on Catnatian inflation. For example, the correlation coefficien between $\dot{p}^{\text {us }}$ and $\dot{\hat{r}}$ is 655 , between $\dot{P}^{\text {is }}$ and DUMC is -.237 and between $\dot{p}^{\text {us }}$ and DUMA is . 198.
} 


\section{Chart 4}

\section{The Contribution of Monetary-Induced U.S. Inflation} to Canadian Inflation

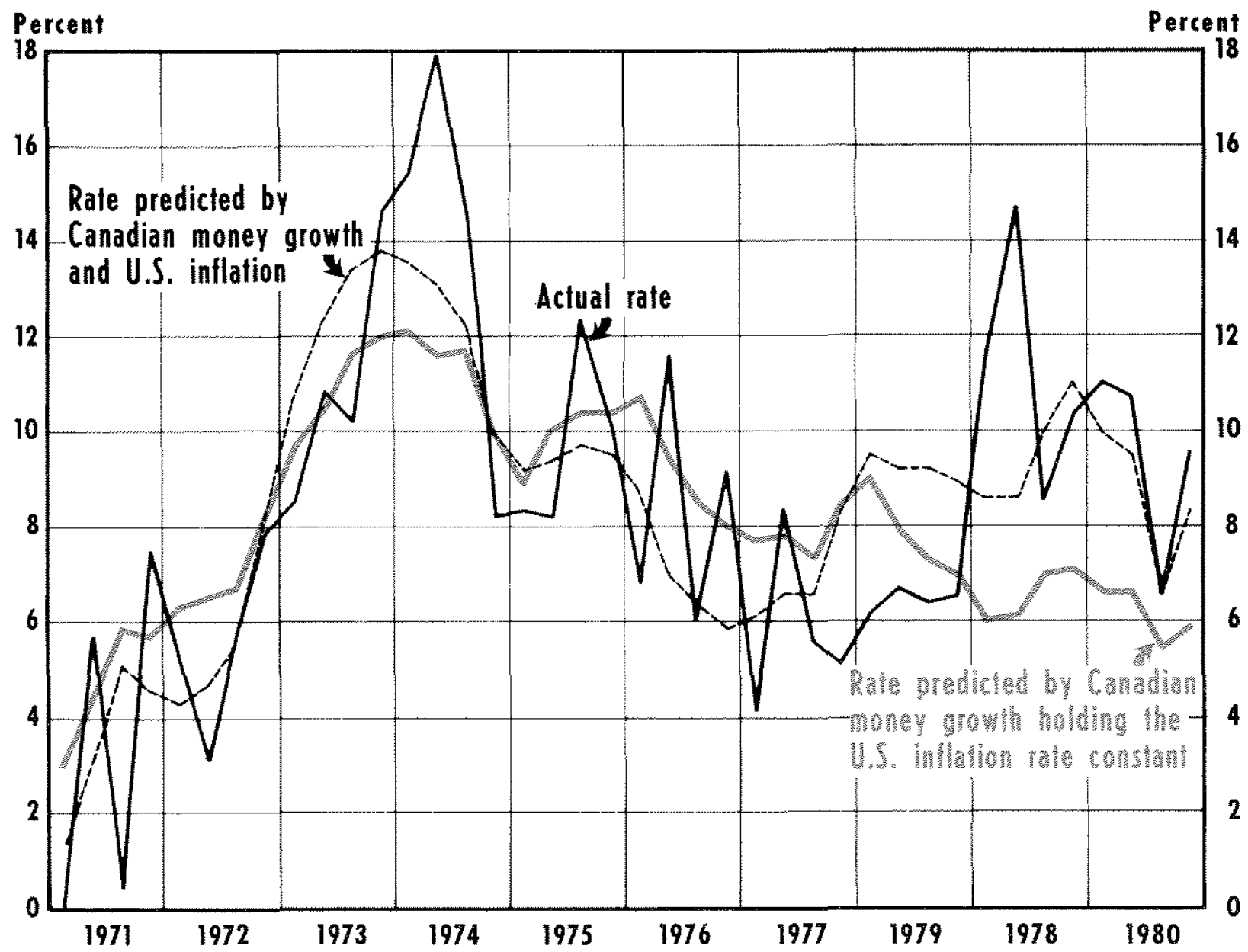

we exclude the dummy variables, the relative energy price and the exchange rate. In this equation, the Canadian inflation rate is explained by only two factors: (1) the long-term rate of money growth in Canada and (2) the U.S. monetary-induced or trend inflation rate.

The Canadian rate of inflation predicted by regression equation 4 in table 3 is shown in chart 4 . To illustrate the role of U.S. inflation in the Canadian price equation, the chart also shows the Canadian inflation rate that would have been predicted by Canadian money growth if the U.S. inflation rate had remained constant throughout the period. ${ }^{3.3}$ The difference be-

\footnotetext{
${ }^{3}$ The U.S. inflation rate is set constant at its quarterly average for the 1971-80 period (equal to .017 when expressed as a fraction per quartery. Under this assumption, the Canadian inflation rate is predicted by the equation: $\dot{\mathrm{p}}^{\mathrm{at}}=-.003+.997 \overline{\mathrm{m}}^{\mathrm{c}: \mathrm{a}}$.
}

tween the two predicted rates can be interpreted as the contribution of the (money-growth-related) U.S. inflation rate to the rate of inflation in Canada. As the chart illustrates, while the U.S. influence (as operating through the U.S. inflation rate) has tended to lower the predicted rate of inflation in Canada during the early 1970 s and in the control period, it has added to the predicted rate during the 1973-74 period and, more recently, in the post-control period. ${ }^{34}$

It was noted earlier that the Canadian rate of inflation has stayed well above the rate predicted by the

\footnotetext{
${ }^{34}$ It is interesting to note that because of lags between U.S. money growh and inflation, the effect of monetary-induced U.S. inflation on Canatian inflation in 1973-74 and the post-control period has, in fact, been produced by rapid U.S. money trowth prior to these periods.
} 
Canadian long-term monetary growth in 1979 and 1980. Chart 4 shows that this difference can be explained for most of the period by taking into account the effect of the monetary-induced U.S. rate of inflation. As can be seen from the chart, although there are large deviations in the first two quarters of 1978, the predicted inflation rate based on both Canadian money growth and U.S. trend inflation rate) tracks the actual inflation rate quite well in the remainder of the 1979-80 period.

The above discussion of the impact of U.S. money growth and inflation on the rate of inflation in Canada has highlighted two channels through which the effect of U, S. money growth is transmitted to Canadian inflation. As illustrated in figure 1, U.S. money growth influences inflation in Canada via: (1) Canadian money growth and (2) U.S. inflation. The first channel operates because of the Bank of Canada's policy of intervening in the exchange market. It is interesting to point out that this policy also may have strengthened the second channel. For instance, if the Bank of Canada had not attempted to influence the exchange rate and followed an independent monetary policy, the exchange rate nay have shown a pronounced trend which may have offset, at least in part, the effect of monetary-induced U.S. inflation on Canadian inflation.

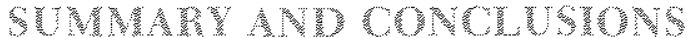

This article has examined the role of a number of factors in determining the rate of Canadian inflation over the last decade. The evidence shows that long- term monetary growth - as measured by the average rate of growth of Canadian $M 1$ over the past 12 quarters-is a key determinant of Canadian inflation. Furthermore, after taking into account the effect of long-term Canadian monetary growth, factors such as wage-push and unemployment did not exert a significant effect on Canada's inflation rate.

The article also has examined the transmission of inflation from the United States to Canada. It finds that long-term U.S. monetary growth-also measured by a 12-quarter average of past money growth rates-contributed significantly to Canadian inflation in two distinct ways: (1) U.S.monetary growth directly affected Canadian monetary growth, and (2) the monetaryinduced portion of U.S. inflation-the part of the inflation rate explained by long-term U.S. monetary growth-directly affected Canadian infation holding constant the effect of Canadian monetary growth). The link between U.S. and Canadian monetary growth arises, in our view, from the Bank of Canada's policy of not allowing the exchange rate to fluctuate freely. Indeed, it is possible that this policy of exchange rate management also may have strengthened the direct link between U.S. and Canadian inflation.

Recently, monetarism has been criticized in Canada because the Bank of Canadi, while apparently successful in reducing the rate of growth of Canadian $M 1$, has been unable to significantly reduce infiation. This article suggests that Canada's difficulties in controlling inflation can be explained, at least in part, by taking into account the effect of U.S. long-term monetary growth on Canadian inflation.

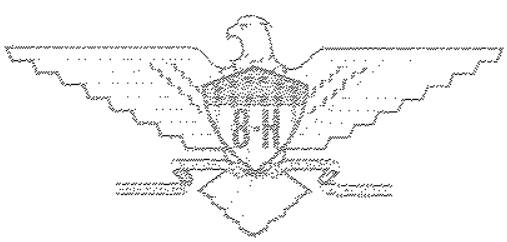

